\title{
Synthesis and Spectral, Thermal and Structural Characterization of a Vitamin B13 Complex of Nickel(II) with 2-Aminothiazole, $m e r-\left[\mathrm{Ni}(\mathrm{HOr})\left(\mathrm{H}_{2} \mathrm{O}\right)_{2}(\text { ata })_{2}\right]$
}

\author{
Okan Zafer Yeşilel ${ }^{\mathrm{a}}$, Kamber Akdağ ${ }^{\mathrm{b}}$, Hümeyra Paşaoğlu ${ }^{\mathrm{b}}$, and Orhan Büyükgüngör ${ }^{\mathrm{b}}$ \\ ${ }^{a}$ Department of Chemistry, Faculty of Arts and Sciences, Eskişehir Osmangazi University, \\ 26480 Eskişehir, Turkey \\ b Department of Physics, Faculty of Arts and Sciences, Ondokuz Mayıs University, \\ 55139, Kurupelit-Samsun, Turkey \\ Reprint requests to Dr. O. Z. Yeşilel. Fax: +90 222 2393578. E-mail: yesilel@ ogu.edu.tr
}

Z. Naturforsch. 2007, 62b, 818-822; received January 2, 2007

\begin{abstract}
The $m e r$-bis(2-aminothiazole)diaqua-orotato-nickel(II) complex, mer-[Ni(HOr) $\left.\left(\mathrm{H}_{2} \mathrm{O}\right)_{2}(\text { ata })_{2}\right](\mathbf{1})$, was synthesized and characterized by spectral (IR and UV/vis) and thermal studies. In addition, the crystal structure of the complex was determined by single crystal X-ray diffraction. The complex crystallizes in the triclinic system, space group $P \overline{1}$. The orotate ligand is coordinated to the nickel(II) atom through a nitrogen atom of the pyrimidine ring and an oxygen atom of the carboxylate group as a bidentate dianion. The coordination of the $\mathrm{Ni}(\mathrm{II})$ ion is extended to six by the two 2-aminothiazoles (ata) and two water molecules. The thermal decomposition has been studied in a static air atmosphere.
\end{abstract}

Key words: Orotato Complex, Vitamin B13 Complex, 2-Aminothiazole

\section{Introduction}

Aminothiazoles are a group of biologically important compounds having a wide range of activities such as anti-tumor, anti-anoxic and anti-oxidant properties $[1,2]$. Previous reports have shown that aminothiazoles possess anti-oxidant activity and inhibit lipid peroxidation [2,3]. 2-Aminothiazoles [Scheme 1. (a)] are known mainly as biologically active compounds with a broad range of activities and as intermediates in the synthesis of antibiotics, well known sulfa drugs, and some dyes [4]. Metal complexes of vitamin B13 [orotic acid, uracil-4-carboxylic acid, 1,2,3,6-tetrahydro-2,6-dioxo-4-pyrimidine carboxylic acid, $\mathrm{H}_{3} \mathrm{Or}$, Scheme 1. (b)] and its derivatives continue to attract attention because of their multidentate functionality and their pivotal role in bioinorganic chemistry [5]. Orotic acid is a precursor in the biosynthesis of pyrimidine bases and nucleic acids in living organisms [6] and has been widely exploited in medicine. Besides its biological importance, vitamin B13 is also an interesting potentially multidentate ligand. It can be coordinated to metal ions through the nitrogen atoms, the two carbonyl oxygen and the carboxylate oxygen atoms as a monodentate, bidentate and polydentate donor. The most common coordination mode of<smiles>O=C(O)c1cc(=O)[nH]c(=O)[nH]1</smiles>

(a)

Scheme 1. (a) Orotic acid, $\mathrm{H}_{3} \mathrm{Or}$, (b) 2-aminothiazole, ata.

$\mathrm{HOr}^{2-}$ is ligation through the deprotonated nitrogen atom of the pyrimidine and one carboxylate oxygen atom so forming a five-membered chelate ring. Crystal structures were described for mononuclear Ni(II)orotate complexes with triethanolamine [7], 4-methylimidazole [8], imidazole [9], nicotine amide [10], water [11,12], 2,2'-bipyridylamine, 1,10-phenanthroline, and 2,9-dimethyl-1-1,10-phenanthroline [13], with the orotate ligands acting as bidentate donors. In polymeric $\left[\mathrm{Ni}(\mathrm{HOr})\left(\mathrm{H}_{2} \mathrm{O}\right)_{3}\right]_{n}[13,14]$ and $\left[\mathrm{Ni}(\mathrm{HOr})\left(\mathrm{NH}_{3}\right)-\right.$ $\left.\left(\mathrm{H}_{2} \mathrm{O}\right)_{2}\right]_{n}$ [15] complexes, orotate acts as a bridging ligand [orotato- $\mathrm{N}(3), \mathrm{O}_{\text {acid }}, \mathrm{O}(6)$ or $\mathrm{O}(2)$ ]. In some of the complexes, orotate acts as a counter ion [15-18]. Orotic acid exhibits a double or triple hydrogenbonding functionality, depending on the metal coor- 
dination mode. The potential for molecular recognition of organic molecules may have interesting implications in both pharmaceutical and materials chemistry, where the orotate or hydrogenorotate anions can be used as versatile synthons for the assembly of metal-organic supramolecular architectures [19]. In this study, we describe the synthesis, spectroscopic (IR and UV/vis), thermal and structural characterization of mer-[Ni(HOr $\left.)\left(\mathrm{H}_{2} \mathrm{O}\right)_{2}(\text { ata })_{2}\right](\mathbf{1})$.

\section{Results and Discussion}

\section{Magnetic susceptibility and UV/vis spectrum}

The Ni(II) complex exhibits a magnetic moment of $2.92 \mathrm{BM}$, which corresponds to two unpaired electrons. The UV/vis spectrum of a solution in $\mathrm{H}_{2} \mathrm{O}$ exhibits absorption bands at $394\left(\varepsilon=18 \mathrm{~L} \mathrm{~mol}^{-1} \mathrm{~cm}^{-1}\right)$, $638(\varepsilon=5)$ and $895 \mathrm{~nm}(\varepsilon=4)$, assigned to the ${ }^{3} \mathrm{~A}_{2 \mathrm{~g}} \rightarrow$ ${ }^{3} \mathrm{~T}_{1 \mathrm{~g}}(\mathrm{P}),{ }^{3} \mathrm{~A}_{2 \mathrm{~g}} \rightarrow{ }^{3} \mathrm{~T}_{1 \mathrm{~g}}$ and ${ }^{3} \mathrm{~A}_{2 \mathrm{~g}} \rightarrow{ }^{3} \mathrm{~T}_{2 \mathrm{~g}} d-d$ transitions, respectively. The $\Delta_{\mathrm{O}}$ value for $\mathrm{Ni}(\mathrm{II})$ has been calculated as $11170 \mathrm{~cm}^{-1}$ [21].

\section{IR Spectrum}

The most significant frequencies in the IR spectrum of $\mathbf{1}$ are given in Table 1 . The spectrum shows a strong band at $3453 \mathrm{~cm}^{-1}$ due to aqua ligands. The bands at 3350 and $3292 \mathrm{~cm}^{-1}$ are attributed to the $\mathrm{NH}_{2}$ stretching vibration of the ata ligands. The weak band at $2937 \mathrm{~cm}^{-1}$ is due to $v_{\mathrm{CH}}$ vibrations. The carbonyl stretching bands of the free orotic acid observed at 1729 and $1719 \mathrm{~cm}^{-1}\left(v_{\mathrm{C}=\mathrm{O}(\text { acid })}+v_{\mathrm{C}(2)=\mathrm{O}}\right)$ and $1700 \mathrm{~cm}^{-1}\left[v_{\mathrm{C}(6)=\mathrm{O}}+v_{\text {ring }}\right]$ [22] are shifted to 1650 and $1625 \mathrm{~cm}^{-1}$ in the spectrum of $\mathbf{1}$. This shift indicates that the orotate ligand is coordinated as a dianion through the nitrogen atom of the pyrimidine ring and an oxygen atom of the carboxylate group. The intense band at $1592 \mathrm{~cm}^{-1}$ corresponds to $v_{\mathrm{CC}}$ vibrations of the pyrimidine ring, while the $v_{(\mathrm{C}=\mathrm{N})}$ and $v_{(\mathrm{C}-\mathrm{N})}$ vibrations are observed at 1534 and $1280 \mathrm{~cm}^{-1}$, respectively.

\section{Thermal analysis}

The thermal decomposition of $\mathbf{1}$ was followed by DTG up to $1000^{\circ} \mathrm{C}$ in a static air atmosphere. The first stage at $147-200{ }^{\circ} \mathrm{C}$ is related to the release of two water ligands with an endothermic effect $\left(\mathrm{DTG}_{\max }=\right.$ $197{ }^{\circ} \mathrm{C}$, mass loss found $9.12 \%$, calcd. $8.03 \%$ ). The following stages at $201-448{ }^{\circ} \mathrm{C}$ are related to the decomposition of the ata ligand and decarboxylation of
Table 1. IR spectral data of $\mathbf{1}\left(\mathrm{cm}^{-1}\right)$ and of orotic acid.

\begin{tabular}{lll}
\hline Assignment & Orotic acid [22] & $\mathbf{1}^{\mathrm{a}}$ \\
\hline$v(\mathrm{OH})$ & $3241 \mathrm{sh}$ & $3453 \mathrm{~s}$ \\
$v\left(\mathrm{NH}_{2}\right)$ & - & $3350,3292 \mathrm{~s}$ \\
$v\left(\mathrm{~N}_{(3)} \mathrm{H}\right)$ & $3154 \mathrm{~m}$ & $3139 \mathrm{~s}$ \\
$v\left(\mathrm{~N}_{(1)} \mathrm{H}\right)$ & $3137 \mathrm{~m}$ & - \\
$v(\mathrm{CH})$ & $3099 \mathrm{~s}$ & $2937 \mathrm{w}$ \\
$v\left(\mathrm{C}=\mathrm{O}_{\text {acid }}+\mathrm{C}_{(2)}=\mathrm{O}\right)$ & $1729,1719 \mathrm{vs}$ & $1650 \mathrm{vs}$ \\
$v(\mathrm{C}(6)=\mathrm{O})+v_{\text {ring }}$ & $1700 \mathrm{vs}$ & $1625 \mathrm{vs}$ \\
$v(\mathrm{C}=\mathrm{C})+v_{\text {ring }}$ & $1653 \mathrm{vs}$ & $1592 \mathrm{vs}$ \\
$v(\mathrm{C}=\mathrm{N})$ & $1435 \mathrm{~s}$ & $1492,1535 \mathrm{~m}$ \\
$v(\mathrm{C}=\mathrm{S})$ & - & $1209 \mathrm{~m}$ \\
\hline
\end{tabular}

a Abbreviations: $\mathrm{w}$ - weak; $\mathrm{m}$ - medium; $\mathrm{s}$ - strong; vs - very strong; $\mathrm{b}$ - broad.

the orotate ligand. The strong exothermic stage is associated with the burning of the organic residue. The final decomposition product is $\mathrm{NiO}$. The total mass loss is $82.80 \%$ (calcd. $83.37 \%$ ) for the $30-525^{\circ} \mathrm{C}$ temperature range.

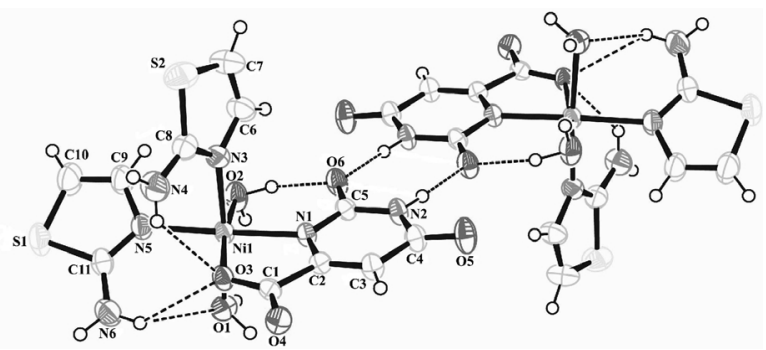

Fig. 1. The AD:DA pairs present in the crystal structure of $\mathbf{1}$, showing the intra- and some of the intermolecular hydrogen bonding.

\section{Crystal structure of 1}

The details of the crystal structure are given in Table 2. The molecular structure is shown in Fig. 1. Selected bond distances and angles are given in Table 3. The crystal structure consists of discrete $\left[\mathrm{Ni}(\mathrm{HOr})\left(\mathrm{H}_{2} \mathrm{O}\right)_{2}(\text { ata })_{2}\right]$ molecules. The $\mathrm{Ni}(\mathrm{II})$ ion has a distorted octahedral configuration with a bidentate $\mathrm{HOr}^{2-}$ ligand, two water and two ata ligands (Fig. 1). The $\mathrm{N}$ and $\mathrm{O}$ atoms of the orotate anion are bonded to the metal cation to form a five-membered chelate ring $[\mathrm{Ni}(1)-\mathrm{N}(1)=2.055(2)$ and $\mathrm{Ni}(1)-\mathrm{O}(1)=2.049(2) \AA]$. All N-Ni-N, N-Ni-O and $\mathrm{O}-\mathrm{Ni}-\mathrm{O}$ bond angles deviate significantly from 90 or $180^{\circ}$, which is presumably a result of the steric constraints arising from the shape of the ligands. The $\mathrm{C}-\mathrm{O}$ distances are almost equal in the uncoordinated $\mathrm{HOr}^{2-}$ anion and its $\mathrm{Ni}(\mathrm{II})$ and $\mathrm{Li}(\mathrm{I})$ complexes [23]. In $\mathbf{1}$, the $\mathrm{C}-\mathrm{O}$ bond lengths are in the range $1.254(3)-1.244(3) \AA$, which is comparable with those in similar $\mathrm{Ni}(\mathrm{II})$ complexes $[8,17]$. 
Table 2. Crystal data and structure refinement parameters for $\mathbf{1}$.

\begin{tabular}{ll}
\hline Empirical formula & $\mathrm{C}_{11} \mathrm{H}_{14} \mathrm{~N}_{6} \mathrm{O}_{6} \mathrm{~S}_{2} \mathrm{Ni}$ \\
Formula weight $\left[\mathrm{g} \mathrm{mol}^{-1}\right]$ & 449.11 \\
Crystal size $\left[\mathrm{mm}^{3}\right]$ & $0.220 \times 0.157 \times 0.070$ \\
Temperature $[\mathrm{K}]$ & $293(2)$ \\
Wavelength $\left(\mathrm{Mo} K_{\alpha}\right)[\AA]$ & 0.71073 \\
Crystal system & triclinic \\
Space group & $P \overline{1}$ \\
Unit cell dimensions: & $8.294(1), 8.710(1), 12.060(1)$ \\
$a, b, c[\AA]$ & $97.42(7), 99.00(1), 95.78(7)$ \\
$\alpha, \beta, \gamma\left[{ }^{\circ}\right]$ & $846.8(1)$ \\
$V\left[\AA^{3}\right]$ & 2 \\
$Z$ & 1.436 \\
Absorption coefficient $\left[\mathrm{mm}^{-1}\right]$ & 1.761 \\
$D_{\text {calc. }}\left[\mathrm{Mg} \mathrm{m}^{-3}\right]$ & $2.51-28.01$ \\
$\theta$ range for data collection $[\mathrm{deg}]$ & 13465 \\
Measured reflections & 3990 \\
Independent reflections & integration \\
Absorption correction & $R_{1}=0.0469 ; w R_{2}=0.1826$ \\
Final $R$ indices $\left[F^{2} \geq 2 \sigma\left(F^{2}\right)\right]$ & $R_{1}($ all data) $=0.9600$ \\
& 0.974 \\
Goodness-of-fit on $F^{2}$ & $0.725 /-0.962$ \\
Largest difference peak and hole & \\
{$\left[\mathrm{e} \AA^{-3}\right]$} & \\
\hline
\end{tabular}

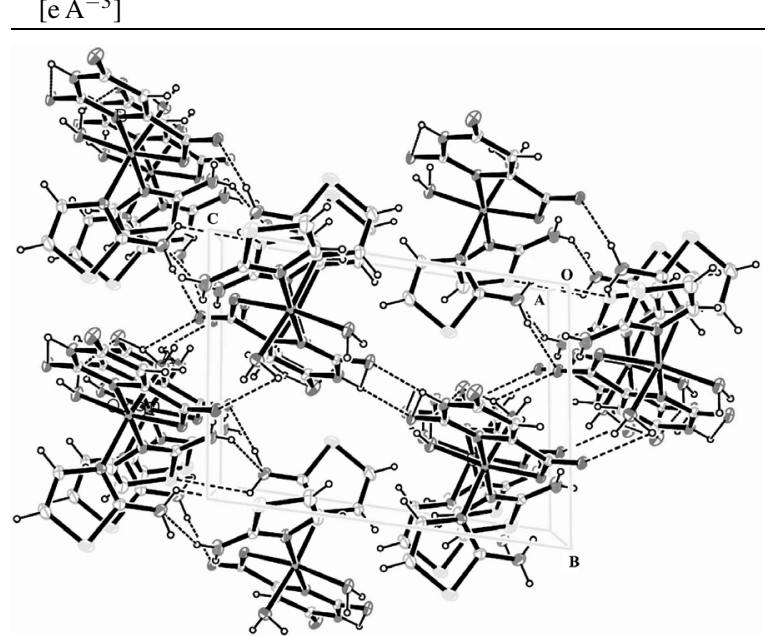

Fig. 2. The hydrogen bonding interactions and the unit cell packing of 1 .

The orotato ligand is almost planar (the r.m.s deviations are $0.0593 \AA$ ). A comparison of the $\mathrm{Ni}-\mathrm{O} 1$, $\mathrm{Ni}-\mathrm{N} 3, \mathrm{M}-\mathrm{N}_{\text {ata }}$ distances, and the $\mathrm{O} 1-\mathrm{Ni}-\mathrm{N} 3$ and $\mathrm{N}_{\text {ata }}-\mathrm{M}-\mathrm{N}_{\text {ata }}$ angles for the orotate and ata metal complexes is given in Table 4.

The crystal is stabilized by strong intermolecular $\mathrm{H}$ bonds $\mathrm{N}-\mathrm{H} \cdots \mathrm{O}$, O-H $\cdots \mathrm{O}$ etc. The details of this hydrogen bonding are given in Table 5 . The orotate ligand is involved in hydrogen bonds with neighboring orotate ligands and aqua ligands through its $\mathrm{N}$ and $\mathrm{O}$ atoms. As shown in Figs. 1 and 2, each of the $\mathrm{HOr}^{2-}$ ligands is doubly $\mathrm{H}$-bonded to a correspond-
Table 3. Selected bond lengths $(\AA)$ and angles $\left({ }^{\circ}\right)$ in $\mathbf{1}$.

\begin{tabular}{lclc}
\hline Ni1-O2 & $2.107(2)$ & Ni1-N1 & $2.055(2)$ \\
Ni1-O3 & $2.049(2)$ & Ni1-N5 & $2.080(3)$ \\
N5-C11 & $1.307(4)$ & S1-C10 & $1.719(4)$ \\
N3-C8 & $1.313(4)$ & S2-C7 & $1.714(5)$ \\
N6-C11 & $1.339(4)$ & C9-C10 & $1.332(5)$ \\
N4-C8 & $1.346(4)$ & C7-C6 & $1.343(5)$ \\
S1-C11 & $1.735(3)$ & N5-C9 & $1.385(4)$ \\
S2-C8 & $1.728(3)$ & N3-C6 & $1.374(4)$ \\
O3-Ni1-N3 & $92.03(9)$ & O3-Ni1-O1 & $83.89(9)$ \\
N1-Ni1-N3 & $90.10(10)$ & N1-Ni1-O1 & $93.65(9)$ \\
N5-Ni1-N3 & $87.57(10)$ & N5-Ni1-O1 & $88.67(10)$ \\
O2-Ni1-N3 & $95.00(10)$ & O1-Ni1-O2 & $89.61(10)$ \\
C11-N5-C9 & $110.4(3)$ & C9-C10-S1 & $110.0(3)$ \\
C8-N3-C6 & $110.9(3)$ & C6-C7-S2 & $110.2(3)$ \\
N3-C8-N4 & $125.1(3)$ & N3-C8-S2 & $113.7(2)$ \\
N5-C11-N6 & $124.4(3)$ & N5-C11-S1 & $113.9(2)$ \\
N4-C8-S2 & $121.2(2)$ & C10-C9-N5 & $116.3(3)$ \\
N6-C11-S1 & $121.7(3)$ & C7-C6-N3 & $115.7(3)$ \\
C10-S1-C11 & $89.45(17)$ & C7-S2-C8 & $89.54(17)$ \\
\hline
\end{tabular}

Table 5. Hydrogen bonding interactions in $\mathbf{1}$.

\begin{tabular}{|c|c|c|c|c|}
\hline$\overline{\mathrm{D}-\mathrm{H} \cdots \mathrm{A}}$ & $\begin{array}{l}d(\mathrm{D}-\mathrm{H}) \\
(\AA)\end{array}$ & $\begin{array}{l}d(\mathrm{H} \cdots \mathrm{A}) \\
(\AA)\end{array}$ & $\begin{array}{l}d(\mathrm{D} \cdots \mathrm{A}) \\
(\AA)\end{array}$ & $\begin{array}{l}<(\text { DHA }) \\
\left({ }^{\circ}\right)\end{array}$ \\
\hline$\overline{\mathrm{N} 2-\mathrm{H} 2 \cdots \mathrm{O}^{1}}$ & 0.86 & 1.98 & $2.826(3)$ & 170.1 \\
\hline $\mathrm{N} 4-\mathrm{H} 4 \mathrm{~A} \cdots \mathrm{S} 1^{\mathrm{ii}}$ & 0.86 & 2.80 & $3.292(3)$ & 118.1 \\
\hline $\mathrm{N} 4-\mathrm{H} 4 \mathrm{~B} \cdots \mathrm{O} 4^{\mathrm{iii}}$ & 0.86 & 2.03 & $2.861(3)$ & 162.8 \\
\hline $\mathrm{N} 6-\mathrm{H} 6 \mathrm{~B} \cdots \mathrm{N} 4^{\mathrm{ii}}$ & 0.86 & 2.54 & $3.320(4)$ & 151.0 \\
\hline $\mathrm{O} 1-\mathrm{H} 1 \mathrm{~A} \cdots \mathrm{O}^{\mathrm{iv}}$ & $0.92(2)$ & $1.90(5)$ & $2.682(3)$ & $141(6)$ \\
\hline $\mathrm{O} 1-\mathrm{H} 1 \mathrm{~B} \cdots \mathrm{O} 4^{\mathrm{v}}$ & $0.93(2)$ & $1.79(2)$ & $2.714(3)$ & $173(6)$ \\
\hline $\mathrm{O} 2-\mathrm{H} 2 \mathrm{~B} \cdots \mathrm{O} 5^{\mathrm{iv}}$ & $0.93(2)$ & $2.20(6)$ & $2.953(4)$ & $137(7)$ \\
\hline $\mathrm{N} 4-\mathrm{H} 4 \mathrm{~A} \cdots \mathrm{O} 3$ & 0.86 & 2.18 & $2.867(3)$ & 136.1 \\
\hline N6-H6A $\cdots \mathrm{O} 1$ & 0.86 & 2.55 & $3.090(4)$ & 121.3 \\
\hline N6-H6A $\cdots \mathrm{O} 3$ & 0.86 & 2.58 & $3.246(4)$ & 135.6 \\
\hline $\mathrm{O} 2-\mathrm{H} 2 \mathrm{~A} \cdots \mathrm{O} 6$ & $0.93(2)$ & $1.77(3)$ & $2.633(3)$ & $153(5)$ \\
\hline
\end{tabular}

ing $\mathrm{HOr}^{2-}$ ligand of another $\mathrm{Ni}(\mathrm{II})$ complex. These DA:AD type hydrogen bonds involve the pyrimidine carbonyl and the amide $\mathrm{N}-\mathrm{H}$ groups $\left[\mathrm{N}(2) \cdots \mathrm{O}(6)^{\mathrm{i}}\right.$ $2.826(3) \AA, \mathrm{H} \cdots \mathrm{O}(6)^{\mathrm{i}} 1.98 \AA, \mathrm{N}(2)-\mathrm{H} \cdots \mathrm{O}(6)^{\mathrm{i}} 170.1^{\circ}$; i: $2-x, 1-y, 1-z]$. Double hydrogen bonds are found in nature in guanine tetrads (or G quartets) [24] which are stabilized by a central sodium ion. Some of these interactions are illustrated in Fig. 2. There are also hydrogen bonds between ata and aqua ligands.

\section{Experimental Section}

All chemicals were purchased as analytical grade. The IR spectrum was obtained with a Bruker Tensor 27 FT-IR spectrometer using $\mathrm{KBr}$ pellets in the $4000-400 \mathrm{~cm}^{-1}$ range. Elemental analyses for $\mathrm{C}, \mathrm{H}$ and $\mathrm{N}$ were performed using a Carlo Erba 1106 microanalyzer. The magnetic susceptibility measurement was performed at r.t. using a Sher- 
Table 4. Comparison of the bond lengths and angles of selected Ni-HOr complexes and $\left[\mathrm{ZnCl}_{2}(\mathrm{ata})_{2}\right]$.

\begin{tabular}{lllll}
\hline Complexes & $\mathrm{Ni}-\mathrm{O} 1(\AA)$ & $\mathrm{Ni}-\mathrm{N} 3(\AA)$ & $\mathrm{O} 1-\mathrm{Ni}-\mathrm{N} 3\left(^{\circ}\right)$ & $\mathrm{M}-\mathrm{N}_{\text {ata }}(\AA) / \mathrm{N}_{\text {ata }}-\mathrm{M}-\mathrm{N}_{\text {ata }}\left({ }^{\circ}\right)$ \\
\hline$\left[\mathrm{Ni}(\mathrm{HOr})\left(\mathrm{H}_{2} \mathrm{O}\right)_{4}\right] \cdot \mathrm{H}_{2} \mathrm{O}[20]$ & $2.023(3)$ & $2.049(3)$ & $80.0(1)$ & - \\
{$\left[\mathrm{Ni}(\mathrm{HOr})\left(\mathrm{H}_{2} \mathrm{O}\right)_{3}\right]_{n}[14]$} & $2.064(2)$ & $2.056(2)$ & $79.41(7)$ & - \\
{$\left[\mathrm{Ni}(\mathrm{HOr})\left(\mathrm{H}_{2} \mathrm{O}\right)_{3}(\mathrm{na})\right] \cdot 2 \mathrm{H}_{2} \mathrm{O}[10]$} & $2.073(1)$ & $2.048(2)$ & $80.21(6)$ & - \\
{$\left[\mathrm{Ni}(\mathrm{HOr})\left(\mathrm{H}_{2} \mathrm{O}\right)(4-\mathrm{mim})_{3}\right]_{2} \cdot 5 \mathrm{H}_{2} \mathrm{O}[8]$} & $2.078(2) / 2.061(2)$ & $2.084(2) / 2.118(2)$ & $79.66(6) / 79.92(6)$ & - \\
{$\left[\mathrm{Ni}(\mathrm{HOr})\left(\mathrm{H}_{2} \mathrm{O}\right)_{2}(\mathrm{im})_{2}\right][9]$} & $2.064(1)$ & $2.072(2)$ & $80.12(5)$ & - \\
{$\left[\mathrm{Ni}(\mathrm{HOr})(\mathrm{bipy})\left(\mathrm{H}_{2} \mathrm{O}\right)_{2}\right] \cdot 2 \mathrm{H}_{2} \mathrm{O}[11]$} & $2.053(3)$ & $2.067(3)$ & $79.47(11)$ & - \\
{$\left[\mathrm{Ni}(\mathrm{HOr})\left(\mathrm{NH}_{3}\right)\left(\mathrm{H}_{2} \mathrm{O}\right)_{2}\right]_{n}[19]$} & $2.08(1)$ & $2.08(1)$ & $78.7(5)$ & - \\
{$\left[\mathrm{Ni}(\mathrm{HOr})\left(\mathrm{H}_{2} \mathrm{O}\right)(\mathrm{tea})\right] \cdot \mathrm{H}_{2} \mathrm{O}[7]$} & $2.029(1)$ & $2.085(2)$ & $80.08(6)$ & - \\
{$\left[\mathrm{ZnCl}(\mathrm{ata})_{2}\right][29]$} & - & - & - & $2.024(2), 2.011(2) / 109.59(2)$ \\
{$\left[\mathrm{NiHOr}\left(\mathrm{H}_{2} \mathrm{O}\right)_{2}(\text { ata })_{2}\right]$ (this work) } & $2.100(2)$ & $2.108(2)$ & $83.89(9)$ & $2.080(3), 2.108(3) / 87.6(1)$ \\
\hline
\end{tabular}

wood Scientific MXI model Gouy magnetic balance. The $\mathrm{UV} / \mathrm{vis}$ spectrum was obtained for an aqueous solution of the complex $\left(10^{-3} \mathrm{M}\right)$ with a Unicam UV2 spectrometer in the range 900-190 nm. A Perkin Elmer Diamond TG/DTA thermal analyzer was used to record simultaneous TG, DTG and DTA curves in static air atmosphere at a heating rate of $10{ }^{\circ} \mathrm{C} \mathrm{min}^{-1}$ in the temperature range $20-1000{ }^{\circ} \mathrm{C}$ using platinum crucibles.

mer-[Ni(HOr $\left.)\left(\mathrm{H}_{2} \mathrm{O}\right)_{2}(\mathrm{ata})_{2}\right](\mathbf{1})$

A solution of 2-aminothiazole $(0.51 \mathrm{~g}, 5 \mathrm{mmol})$ in ethanol $(10 \mathrm{~mL})$ was added dropwise and with stirring to a solution of $\left[\mathrm{Ni}(\mathrm{HOr})\left(\mathrm{H}_{2} \mathrm{O}\right)_{4}\right] \cdot \mathrm{H}_{2} \mathrm{O}$ [20] $(0.76 \mathrm{~g}, 2.5 \mathrm{mmol})$ in distilled water $(30 \mathrm{~mL})$. The solution was heated to $60{ }^{\circ} \mathrm{C}$ in a temperature-controlled bath and stirred for $5 \mathrm{~h}$. The reaction mixture was then cooled to r.t. The blue crystals formed were filtered, washed with ethanol and dried in air. $\mathrm{C}_{11} \mathrm{H}_{14} \mathrm{~N}_{6} \mathrm{O}_{6} \mathrm{~S}_{2} \mathrm{Ni}$ (449.11): calcd. C 29.42, H 3.16, N 18.71; found C 29.34, H 3.16, N 18.73.

\section{Crystallographic analysis}

Diffraction experiments were carried out at $296 \mathrm{~K}$ on a Stoe IPDS diffractometer. The structure was solved by Direct Methods using the program SHELXS-97 [25]. All nonhydrogen atoms were refined anisotropically by full-matrix least-squares methods with SHELXL-97 [25]. All hydrogen atoms except H1A, H1B, H2A and H2B were located. Data collection: X-Area; cell refinement: X-Area; data reduction: X-RED [26]; molecular graphics: ORTEP-3 for Windows [27]; software used to prepare material for publication: WinGX [28].

CCDC 632158 contains the supplementary crystallographic data for this paper. These data can be obtained free of charge from The Cambridge Crystallographic Data Centre via www.ccdc.cam.ac.uk/data_request/cif.

\section{Acknowledgement}

This work was supported by the Eskisehir Osmangazi University (project No 200619013).
[1] M. Ohkubo, A. Kuno, I. Nakanishi, H. Takasughi, Chem. Pharm. Bull. 1995, 43, 1497.

[2] O. Uchikawa, K. Fukatsu, M. Suno, T. Aono, T. Doi, Chem. Pharm. Bull. 1996, 44, 2070.

[3] K. Aruna, R. Rajagopalan, S. V. Penumathsa, V. P. Menon, Fundamental and Clinical Pharmacology 2004, $18,565$.

[4] U. G. Ibatullin, T. F. Petrushina, L. Y. Leitis, I. Z. Minibaev, B. O. Logvin, Khim. Geterotsikl. Soedin (USSR) $1993,715$.

[5] J. Leberman, A. Kornberg, E. S. Simms, J. Biol. Chem. 1955, 215, 403.

[6] A. Lehninger, Principles of Biochemistry, Worth Publishers, New York, 1970, pp. 661.

[7] O.Z. Yeşilel, H. Ölmez, İ. Uçar, A. Bulut, C. Kazak, Z. Anorg. Allg. Chem. 2005, 631, 3100.

[8] O.Z. Yeşilel, M. S. Soylu, H. Ölmez, O. Büyükgüngör, Polyhedron 2006, 25, 2985.
[9] I. Uçar, A. Bulut, O.Z. Yeşilel, H. Olmez, O. Büyükgüngör, Acta Crystallogr. 2004, C60, m563.

[10] D. A. Kose, B. Zumreoglu-Karan, C. Unaleroglu, O. Şahin, O. Büyükgüngör, J. Coord. Chem. 2006, 59, 2125.

[11] A. Karipides, B. Thomas, Acta Crystallogr. 1986, C42, 1705.

[12] L. Xing, C. Rong, S. Dao-Feng, H. Mao-Chun, Chinese J. Struct. Chem. 2002, 21, 374.

[13] M. J. Plater, M. R. J. Foreman, J. M. S. Skakle, R. A. Howie, Inorg. Chim. Acta 2002, 332, 135.

[14] D. Sun, R. Cao, Y. Liang, M. Hong, Y. Zhao, J. Weng, Aust. J. Chem. 2002, 55, 681.

[15] I. Mutikainen, Finn. Chem. Lett. 1985, 193.

[16] I. Bach, O. Kumberger, 22 H. Schmidbaur, Chem. Ber. 1990, 123, 2267.

[17] L. R. Falvello, D. Ferrer, T. Soler, M. Tomás, Acta Crstallogr. 2003, C59, m149. 
[18] O.Z. Yeşilel, H. Ölmez, J. Therm. Anal. Calorim. 2006, 86, 211.

[19] S. Bekiroglu, O. Kristiansson, J. Chem. Soc., Dalton Trans. 2002, 1330.

[20] I. Mutikainen, P. Lumme, Acta Crystallogr. 1980, B36, 2233.

[21] D. Sutton, Electronic Spectra of Transition Metal Complexes, McGraw-Hill, London, 1968, pp. 208.

[22] A. Hernanz, F. Billes, I. Bratu, R. Navarro, Biopolymers (Biospectroscopy) 2000, 57, 187.

[23] M. Lutz, Acta Crystallogr. 2001, E57, m103.

[24] G. Laughlan, A. I. H. Murchie, D. G. Norman, M. H. Norman, M. H. Moore, P. C. E. Moody, D. M. J. Lilley, B. Luisi, Science 1994, 265, 520.
[25] G. M. Sheldrick, SHELXs/L-97, Programs for the Determination of Crystal Structures, University of Göttingen, Göttingen (Germany) 1997.

[26] X-RED, Stoe \& Cie., Darmstadt (Germany) 2002.

[27] C. K. Johnson, M. N. Burnett, ORTEP-III (version 1.0.2), Rep. ORNL-6895. Oak Ridge National Laboratory, Oak Ridge, TN (USA) 1996.

[28] L. J. Farrugia, WinGX, Suite for Single Crystal Small Molecule Crystallography, University of Glasgow, Glasgow, Scotland (U.K.) 1999. See also: J. Appl. Crysallogr. 1999, 32, 837.

[29] J. J. Macícek, K. K. Davarski, Acta Crystallogr. 1993, C49, 592. 